\title{
Atypical Teratoid/Rhabdoid Tumors in Adults: A Case Report and Treatment-Focused Review
}

\author{
Nicole A. Shonka ${ }^{\mathrm{a}, \mathrm{g}}$, Terri S. Armstrong ${ }^{\mathrm{b}}$, Sujit S. Prabhuc, Amanda Childress ${ }^{\mathrm{d}}$, Shauna Choie, \\ Lauren A. Langford ${ }^{\mathrm{f}}$, Mark R. Gilbert ${ }^{\mathrm{b}}$
}

\begin{abstract}
Atypical teratoid/rhabdoid tumor is predominantly a childhood tumor and has only been rarely reported in adults; therefore, treatment regimens are often extrapolated from the pediatric experience. Typically, children are treated with craniospinal radiation therapy which is often followed by systemic chemotherapy. Employing pediatric regimens to treat this tumor in adult patients poses a particular risk for myelosuppression, as the prescribed doses in pediatric protocols exceed those tolerated by adults, and conventional craniospinal radiation can be associated with prolonged myelotoxicity and a depletion of the bone marrow reserve in vertebrae of adults. Here we present a case of a woman with a pineal region atypical teratoid/rhabdoid tumor, an unusual adult cancer presenting in an atypical location. This is followed by a review of the disease in adult patients with an emphasis on treatment and suggestions to minimize myelotoxicity.
\end{abstract}

Keywords: Atypical rhabdoid tumor; AT/RT; Pineal tumor; Adult

Manuscript accepted for publication March 10, 2011

${ }^{a}$ Division of Oncology and Hematology, University of Nebraska Medical Center, 987680 Nebraska Medical Center, Omaha NE 68198-7680, USA

${ }^{\mathrm{b}}$ Department of Neuro-Oncology, University of Texas at MD Anderson Cancer Center, 1400 Holcombe, Unit 431, Houston, Texas 77030, USA 'Department of Neurosurgery, University of Texas MD Anderson Cancer Center, 1400 Holcombe, Unit 442, Houston, Texas 77030, USA

${ }^{\mathrm{d} B r a i n}$ and Spine Center, University of Texas at MD Anderson Cancer Center, 1515 Holcombe Blvd, Houston, TX 77030, USA

${ }^{e}$ Division of Pharmacy, Department of Neuro-Oncology, University of Texas at MD Anderson Cancer Center, 1400 Holcombe, Unit 431, Houston, Texas 77030, USA

${ }^{\mathrm{f}}$ Department of Pathology/Neuropathology, University of Texas at MD Anderson Cancer Center, 1400 Holcombe, Houston, Texas 77030, USA

g'Corresponding author: Nicole A. Shonka, Email: nshonka@unmc.edu

doi:10.4021/jocmr535w

\section{Case Report}

A 33-year-old right-handed woman developed the sensation of fullness in her head followed months later by blurred vision that progressed to double vision. Brain MRI identified a large pineal mass and hydrocephalus (Fig. 1). A subtotal resection of the mass with concurrent placement of a ventriculoperitoneal shunt was performed at an outside institution (Fig. 2). Pathology suggested an epithelioid neoplasm, but a definitive diagnosis could not be made. Three weeks later, the tumor had regrown to its original size and a repeat supracerebellar infratentorial craniotomy was performed at MD Anderson Cancer Center with a near complete resection of the pineal mass (Fig. 3). Immunohistochemistry was positive for epithelial membrane antigen and smooth muscle actin. An antibody against the hSNF5/INI1 protein was negative in tumor cell nuclei. These findings confirmed the diagnosis of atypical teratoid/rhabdoid tumor (AT/RT), WHO grade IV. Cerebrospinal fluid and spinal MRIs were negative for tumor dissemination.

Peripheral blood stem collection was performed prior to the initiation of chemotherapy. The patient underwent cra-

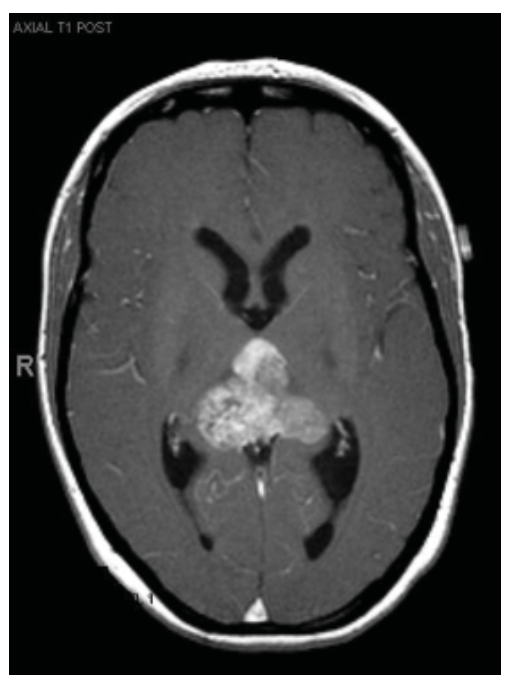

Figure 1. Pre-operative MRI. 


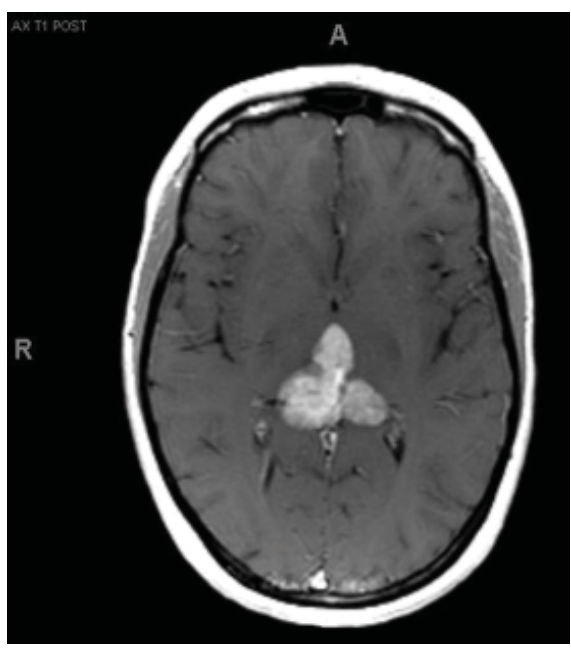

Figure 2. MRI after first resection.

niospinal radiation therapy (CSRT) and post-radiation MRI showed a modest decrease in the size of the residual tumor. Chemotherapy with Ifosphamide, Etoposide and Carboplatin (ICE) was given in 3-week cycles. After two cycles, brain MRI showed a partial tumor response. After her eighth cycle there was evidence of tumor progression with recurrence in the thalamus as well as along the occipital horn of the lateral ventricle. The treatment regimen was changed to doxorubicin, vincristine and temozolomide. The patient continues on this treatment regimen, and remains clinically and radiographically stable 18 months after the initial diagnosis.

\section{Review of the Literature}

\section{The history of AT/RT}

Beckwith and Palmer, in 1978, first coined the term 'rhabdoid tumor' to describe a histological variant of Wilm's tumor found primarily in infants that was associated with an extremely poor prognosis [1]. The name was derived from its similarity in gross tumor appearance to a rhabdomyosarcoma; however, the cells differed from the expected morphological and immunohistochemical features of muscle [2]. A tumor composed of rhabdoid cells in the central nervous system (CNS), was first reported in 1985 [3]. The name 'atypical teratoid/rhabdoid tumor' (AT/RT) exemplifies the tumor's disparate mixtures of rhabdoid, primitive neuroepithelial, mesenchymal and epithelial components [4]. AT/RT is much more frequently seen in infants and young children than older children and is rare in adults. AT/RT has an overall incidence of 1 - 2\% of all brain tumors in children [4, 5]. They are estimated to account for over $10 \%$ of CNS tumors in infants, with a male preponderance up to the age of 3 which then seems to disappear $[6,7]$. There exists a rhabdoid tumor predisposition syndrome which can be inherited

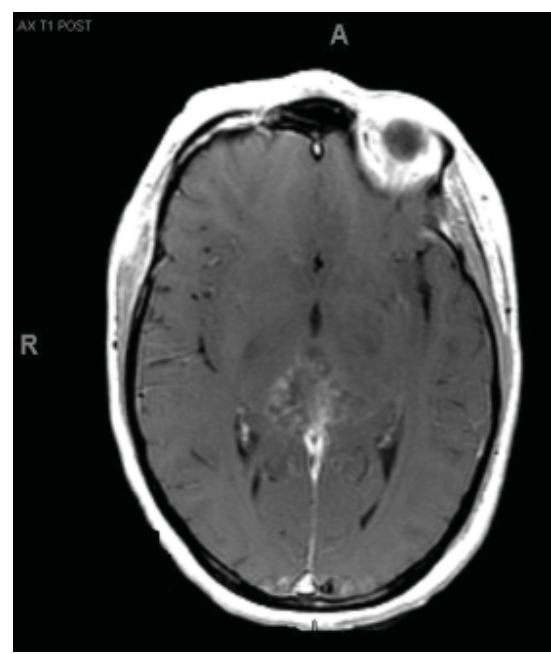

Figure 3. MRI after second resection.

in an autosomal dominant fashion, but most commonly occurs sporadically. The genetic form of AT/RT results from a germline loss of function mutations in INI1, also known as SMARCB1, a tumor suppressor gene at 22q11.23 [8]. This syndrome commonly manifests in tumors of the kidneys, brain and soft tissues. There have been just over 30 adult cases reported in the literature to date [9-31] (summarized in Table 1). Clinical presentation varies with tumor location in adults where a variety of primary locations have been reported.

No data exists to support imaging characteristics that differentiate AT/RTs from other primitive neuroectodermal tumors [32]. Report from the AT/RT workshop in 2002 noted that half of all AT/RTs are in the posterior fossa, although the tumor has been noted throughout the nervous system and in extramedullary sites. Tumors can be extraaxial and invade adjacent structures such as the meninges as well [32]. In adults, these are primarily found in the cerebral hemispheres [33] and are rare in the cerebellum and spinal cord [16, 17, 19, 21, 25]. Similar to our case, two other adult AT/RTs have been found in the pineal region [23, 34].

Computed tomography (CT) usually shows a hyperdense mass that intensely enhances after administration of intravenous contrast. On T1-weighted magnetic resonance imaging (MRI) the mass is commonly isointense with hyperintense areas that result from intratumoral bleeding. The T2 imaging is more heterogenous with hypointense to hyperintense areas indicating a mixture of necrosis, hemorrhage, cystic changes, and calcifications [32, 35]. Peritumoral edema was variable in the meta-analysis of 133 patients done by Oka [36]. MR spectroscopy shows a marked elevation of choline and low or absent N-acetylaspartate (NAA) and creatinine, as would be expected. In a review of thirteen patients ages 4 months to 15 years with AT/RT, all tumors except one enhanced with contrast on MRI [35].

AT/RTs consist of a combination of rhabdoid, primitive 
Table 1. Adult Patients With AT/RT in the CNS

\begin{tabular}{|c|c|c|c|c|c|c|c|c|c|c|}
\hline Author (year) (ref) & $\begin{array}{l}\text { Age } \\
\text { (yr)/ } \\
\text { Sex }\end{array}$ & $\begin{array}{l}\text { Tumor } \\
\text { Location }\end{array}$ & Immunostains & LMD & $\begin{array}{l}\text { Diagnosis } \\
\text { Confirmed }\end{array}$ & $\begin{array}{l}\text { INI1 } \\
\text { Analysis }\end{array}$ & $\begin{array}{l}\text { Primary } \\
\text { Treatment }\end{array}$ & $\begin{array}{l}\text { Secondary } \\
\text { Treatment }\end{array}$ & $\begin{array}{l}\text { TTP } \\
\text { (mos) }\end{array}$ & $\begin{array}{l}\text { OS } \\
\text { (mos) }\end{array}$ \\
\hline Balaton (1987) [27] & $59 \mathrm{M}$ & Paravertebral & CK Vim & $\mathrm{Y}$ & IHC & $\mathrm{N}$ & None & $\mathrm{n} / \mathrm{a}$ & $\mathrm{n} / \mathrm{a}$ & 0.5 \\
\hline Horn (1992) [9] & $21 \mathrm{M}$ & L temporal & EMA Vim & $\mathrm{N}$ & $\mathrm{IHC}$ & $\mathrm{N}$ & STR & STR CT & 48 & 72 \\
\hline Cossu (1993) [26] & $18 \mathrm{M}$ & L frontal & CK EMA Vim & $\mathrm{N}$ & IHC & $\mathrm{N}$ & GTR CT & STR & 5 & 18 \\
\hline Fisher (1996) [10] & $32 \mathrm{M}$ & L caudate & $\begin{array}{l}\text { cGFAP S100 } \\
\text { Vim }\end{array}$ & $\mathrm{Y}$ & IHC & $\mathrm{N}$ & None & $\mathrm{n} / \mathrm{a}$ & $\mathrm{n} / \mathrm{a}$ & 1 \\
\hline Ashraf (1997) [11] & $34 \mathrm{M}$ & L parietal & Vim & $\mathrm{N}$ & IHC & $\mathrm{N}$ & STR RT & STR & 2 & 6 \\
\hline Byram (1999) [12] & $35 \mathrm{M}$ & L temporal & NA & $\mathrm{N}$ & NA & NA & GTR RT & GTR & 36 & 60 \\
\hline Sugita (1999) [34] & $27 \mathrm{M}$ & Pineal region & $\begin{array}{l}\text { chrA EMA NSE } \\
\text { S100 Vim }\end{array}$ & $\mathrm{N}$ & IHC & $\mathrm{N}$ & $\begin{array}{l}\text { STR CRT } \\
\text { ACNU }\end{array}$ & STR & 18 & 24 \\
\hline Kuge (2000) [13] & $32 \mathrm{~F}$ & Suprasellar & $\begin{array}{l}\text { CK EMA SMA } \\
\text { Vim }\end{array}$ & $\mathrm{Y}, \mathrm{r}$ & IHC & $\mathrm{N}$ & STR & $\begin{array}{l}\text { CSRT } \\
\text { CDDP, } \\
\text { VP16, IFN } \\
\text { IT mtx }\end{array}$ & 1 & $8^{+}$ \\
\hline Arrazola (2000) [14] & $20 \mathrm{M}$ & L parietal & $\begin{array}{l}\text { CK EMA S100 } \\
\text { Vim }\end{array}$ & $\mathrm{N}$ & IHC & $\mathrm{N}$ & GTR & GTR CSRT & 3 & 84 \\
\hline Lutterbach (2001) [15] & $30 \mathrm{~F}$ & Cerebellum & CK S100 Vim & $\mathrm{N}$ & IHC & $\mathrm{N}$ & $\begin{array}{l}\text { GTR } \\
\text { RT }\end{array}$ & SRS Tmz & 6 & 11 \\
\hline Bruch (2001) [16] & $21 \mathrm{~F}$ & Spinal cord & CK EMA Vim & $\mathrm{N}$ & IHC, 22qdel & $\mathrm{N}$ & NA & NA & NA & 6 \\
\hline Bruch (2001) [16] & $34 \mathrm{~F}$ & Parietal & CK EMA Vim & $\mathrm{N}$ & IHC, 22qdel & $\mathrm{N}$ & NA & NA & NA & 6 \\
\hline Pimentel (2003) [17] & $31 \mathrm{~F}$ & R parietal & $\begin{array}{l}\text { EMA GFAP } \\
\text { S100 Vim } \\
\text { alpha1ac/at }\end{array}$ & $\mathrm{Y}$ & IHC & $\mathrm{N}$ & STR & $\begin{array}{l}\text { CSRT } \\
\text { ICE }\end{array}$ & 1 & 6 \\
\hline Kachhara (2003) [19] & $35 \mathrm{M}$ & Thalamus & Vim & $\mathrm{N}$ & IHC & $\mathrm{N}$ & $\begin{array}{l}\text { STR } \\
\text { RT }\end{array}$ & - & 2 & NA \\
\hline Kawaguchi (2004) [18] & $22 \mathrm{M}$ & L cerebellum & $\begin{array}{l}\text { CK EMA NSE } \\
\text { SMA Vim }\end{array}$ & $\mathrm{Y}$ & IHC & $\mathrm{N}$ & $\begin{array}{l}\text { STR } \\
\text { CSRT } \\
\text { ICE IT } \\
\text { mtx }\end{array}$ & - & $\mathrm{n} / \mathrm{a}$ & $24+$ \\
\hline Raisanen (2005) [20] & $45 \mathrm{M}$ & $\mathrm{R}$ cerebellum & $\begin{array}{l}\text { CK EMA S100 } \\
\text { SMA Vim }\end{array}$ & $\mathrm{N}$ & IHC & $\mathrm{Y}$ & Sx CT RT & NA & NA & $15+$ \\
\hline Raisanen (2005) [20] & $20 \mathrm{~F}$ & Sella & $\begin{array}{l}\text { CK EMA SMA } \\
\text { Vim }\end{array}$ & $\mathrm{N}$ & IHC & $\mathrm{Y}$ & Sx R CT & CT & NA & $28+$ \\
\hline Raisanen (2005) [20] & $31 \mathrm{~F}$ & Sella & CK EMA Vim & $\mathrm{N}$ & IHC & $\mathrm{Y}$ & Sx RT & NA & NA & 9 \\
\hline Erickson (2005) [21] & $20 \mathrm{~F}$ & R occiput & $\begin{array}{l}\text { EMA GFAP } \\
\text { SMA Vim }\end{array}$ & $\mathrm{N}$ & IHC & $\mathrm{Y}$ & GTR & RT & NA & NA \\
\hline Chen (2006) [28] & $19 \mathrm{M}$ & Post fossa & NA & NA & NA & NA & GTR & CSRT & 7 & 56.5 \\
\hline Ingold (2006) [22] & $45 \mathrm{~F}$ & Pineal & $\begin{array}{l}\text { CK EMA SMA } \\
\text { Vim }\end{array}$ & $\mathrm{Y}, \mathrm{r}$ & IHC & $\mathrm{Y}$ & GTR CRT & GTR & 6 & 7 \\
\hline Rezanko (2006) [23] & $27 \mathrm{M}$ & $\mathrm{R}$ frontal & EMA S100 Vim & $\mathrm{Y}, \mathrm{r}$ & IHC & $\mathrm{N}$ & GTR RT & - & 4 & 4 \\
\hline Chacko (2007) [29] & $23 \mathrm{M}$ & $\mathrm{R}$ frontal & EMA SMA Vim & $\mathrm{N}$ & IHC & $\mathrm{Y}$ & $\begin{array}{l}\text { STR } \\
\text { RT }\end{array}$ & GTR & 1 & 2 \\
\hline Zarovnaya (2007) [24] & $43 \mathrm{~F}$ & Spinal cord & EMA & $\mathrm{Y}, \mathrm{r}$ & IHC & $\mathrm{Y}$ & STR RT & $\begin{array}{l}\text { CSRT } \\
\text { Tmz IFN }\end{array}$ & 2 & 30 \\
\hline Makuria (2008) [30] & $23 \mathrm{M}$ & L temporal & $\begin{array}{l}\text { CK EMA NF } \\
\text { SMA } \\
\text { Syn Vim }\end{array}$ & $\mathrm{N}$ & IHC & $\mathrm{Y}$ & Sx RT CT & - & $\mathrm{n} / \mathrm{a}$ & $30+$ \\
\hline Makuria (2008) [30] & $25 \mathrm{~F}$ & R frontal & $\begin{array}{l}\text { NF SMA Syn } \\
\text { Vim }\end{array}$ & $\mathrm{N}$ & IHC & $\mathrm{Y}$ & GTR & $\begin{array}{l}\text { GTRx5 } \\
\text { GKS RT }\end{array}$ & 24 & $204+$ \\
\hline Makuria (2008) [30] & $42 \mathrm{M}$ & $\begin{array}{l}\mathrm{R} \text { frontal- } \\
\text { parietal }\end{array}$ & CK EMA Vim & $\mathrm{N}$ & IHC & $\mathrm{Y}$ & $\begin{array}{l}\text { STR } \\
\text { RT } \\
\text { CT }\end{array}$ & - & - & $18+$ \\
\hline Makuria (2008) [30] & $37 \mathrm{M}$ & $\begin{array}{l}\mathrm{R} \text { frontal- } \\
\text { parietal }\end{array}$ & Vim & $\mathrm{N}$ & IHC & $\mathrm{Y}$ & NA & NA & & NA \\
\hline Arita (2008) [31] & $56 \mathrm{~F}$ & $\begin{array}{l}\text { Sella/cav } \\
\text { sinus }\end{array}$ & EMA NF Vim & $\mathrm{Y}, \mathrm{r}$ & IHC & $\mathrm{Y}$ & STR SRS & CSRT & 12 & 23 \\
\hline Samaras (2009) [25] & $18 \mathrm{M}$ & $\begin{array}{l}\mathrm{R} \text { frontal- } \\
\text { temporal }\end{array}$ & $\begin{array}{l}\text { EMA GFAP } \\
\text { SMA Vim }\end{array}$ & $\mathrm{N}$ & IHC & $\mathrm{Y}$ & $\begin{array}{l}\text { GTR } \\
\text { RT } \\
\text { GTR }\end{array}$ & - & - & 4 \\
\hline Our patient & $33 \mathrm{~F}$ & Pineal region & EMA SMA & $\mathrm{N}$ & IHC & $\mathrm{Y}$ & $\begin{array}{l}\text { CSRT } \\
\text { ICE }\end{array}$ & $\mathrm{Tmz}+\mathrm{Vcr}$ & 8 & $18+$ \\
\hline
\end{tabular}

LMD: leptomeningeal disease; Y: yes; N: no; Y, r: yes at recurrence; IHC: Immunohistochemistry; NA: not available; STR: subtotal resection; GTR: gross total resection; CT: chemotherapy; CRT: chemoradiation; RT: radiation therapy; CSRT: craniospinal radiation therapy; IT: intrathecal; Sx: surgery (extent unknown); n/a: not applicable; CK: cytokeratin; Vim: vimentin; EMA: epithelial membrane antigen; cGFAP: cytoplasmic glial fibrillary acid protein; SMA: smooth muscle actin; chrA: chromogranin A; NSE: neuron-specific enolase; alpha1ac/at: alpha-1 antichymotrypsin/ antitrypsin; NF: neurofibromin; ACNU: Nimustine; ICE: ifosphamide, carboplatin, etoposide; mtx: methotrexate; SRS: stereotactic radiosurgery; CDDP: Cisplatin; VP16: etoposide; IFN: interferon-gamma; Tmz: temozolomide; GKS: gamma-knife surgery; Vcr: vincristine. 
neuroepithelial, mesencymal and epithelial cells. Approximately one-third contain epithelial or mesenchymal cells, and only $10 \%$ are comprised purely of rhabdoid cells [32]. This heterogeneity makes the discrimination between AT/RT and the other tumors of embryonal tissue, namely medulloblastoma and primitive neuroectodermal tumor (PNET), difficult using histologic criteria [37, 38]. Thus far, the histogenesis of this tumor has remained elusive [10, 32, 39]. Proliferative activity is high, and Ki-67/MIB-1 labelling indices averaged $63.9 \%$ in a series of pediatric patients [40], and have ranged from less than $20 \%$ to $80 \%$ [9, 12, 16, 34].

Immunohistochemistry (IHC) is positive for rhabdoid cell markers including epithelial membrane antigen (EMA), vimentin, and smooth-muscle actin (SMA) in the majority of tumors and markers for germ-cell tumors such as alpha-fetoprotein and placental alkaline phosphatase are consistently negative [4, 32]. The tumors may also express glial fibrillary acidic protein, keratin, synaptophysin, and neurofilament protein [32]. IHC staining for the INI1 protein, a component of a SWI/SNF ATP-dependent chromatin-remodeling complex has been shown to be highly sensitive and specific for AT/RTs [41-43]. Versteege suggested that any loss-of-function mutations of INI1 contribute to oncogenesis after noting bi-allelic alterations of INI1 (i.e., any truncating mutation of one allele caused loss of the other allele). Monosomy 22 or deletions of chromosome band 22q11 are found in most AT/RTs, however, alterations of chromosome 22 are shared in other CNS tumors as well. PNETs may have deletions of chromosome 22 but can sometimes be differentiated from AT/RTs by the presence of chromosome 17 abnormalities [4, 42, 44].

\section{Prognosis}

Tekautz and colleagues reported the outcomes from a series of 37 pediatric patients [7]. Event-free survival (EFS) and overall survival (OS) at two years for children aged three years or older was $78 \%$ and $89 \%$ vs $11 \%$ and $17 \%$ for younger children. Oka performed a meta-analysis of 133 patients and found that 98 (74\%) patients had succumbed to their disease within 24 months of diagnosis, with a mean OS of 8.5 months. Seventy-five percent of these patients were younger than three years of age [36]. Recently, the modified IRS-III regimen evaluated by Chi and colleagues increased two-year survival to $70 \% \pm 10 \%$ compared to historic median survival of only 6 - 11 months [32, 39, 45]. Of the 31 adult patients whose survival data were reported in the literature, the median survival was 15 - 18 months, although it ranged widely from two weeks to over 17 years (Table 1).

\section{Treatment}

The impact of the extent of surgical resection on outcome has not been fully studied. Packer reported from the pediat- ric AT/RT registry an OS of 8.5 months that lengthened to 13 months in patients who had gross total resection (GTR) of their tumors. In this report, a personal communication with J. Hilden M.D. is cited that of the eight patients in the registry with an OS of greater than 18 months, six of those had undergone a GTR [32]. Hilden's report favors more aggressive resection as well with an OS of 20 months vs 15.25 months [46].

Treatment paradigms for adult patients have been extracted from the pediatric literature. Chemotherapeutic regimens used in the pediatric population vary, but regimens commonly utilize vincristine with an alkylating and a platinum agent. Table 2 highlights several regimens and outcomes in pediatric patients.

Excluding our patient, there have been 31 adult cases reported in the (English) literature. There is no information available regarding treatment given to three of these patients, and no survival information was provided for three patients. Of the 28 adult patients in whom treatment was reported, 14 (50\%) received chemotherapy, either concurrent with or after radiation therapy. Temozolomide and ICE were commonly used. Survival in patients who received chemotherapy ranged from 6 months to 17 years, with a median survival of 24 months. Those who received surgery and radiation therapy without chemotherapy had a survival between 2 and 7 years, with a median survival of 9 months. In a small case series, we cannot confirm the superiority of one regimen or even a benefit from chemotherapy. The data supports the importance of preserving bone marrow function so that systemic chemotherapy remains a viable option.

Much of the data regarding treatment has focused on chemotherapy, since the majority of patients diagnosed with AT/RT are under two to three years old when RT is avoided if possible. Those patients over the age of three are routinely given RT, often in the form of CSRT as leptomeningeal disease (LMD) is often present at diagnosis and is common at recurrence. The AT/RT registry shows a high rate of local recurrence, and those who survived more than 18 months were more likely (75\%) to have received RT [32]. Patients are given varying doses between 40 - $60 \mathrm{~Gy}$, and stereotactic radiosurgery has been used for recurrent disease when resection is not feasible [47]. There are no data on the response to $\mathrm{RT}$ in adult AT/RT but of 13 patients in a case series from the Children's Hospital of Philadelphia, only two patients had an objective response [4].

In the report on 42 pediatric cases by Hilden, 13 patients underwent stem cell rescue as part of their primary treatment, which underscores the significant myelosuppression of treatment regimens for AT/RT [46]. Approximately 40\% of adult bone marrow resides in the spine [48]. In our patient, we were concerned about the additive myelotoxicity of CSRT and chemotherapy and so a stem cell harvest was performed and the patient was given radiation with protons. Unlike conventional photon radiotherapy, proton radiotherapy focuses 
Table 2. Chemotherapy Used for AT/RT in Children

\begin{tabular}{|c|c|c|c|c|}
\hline Author (year) (ref) & $\begin{array}{l}\text { Age range } \\
\text { at } \mathrm{dx}\end{array}$ & $\mathbf{n}$ & First line Chemotherapy & Outcomes \\
\hline Biegel (1990) [44] & 6 mos -12 mos & 3 & $\begin{array}{l}\text { Cy, VP-16, Cis, Vcr/Cis, Cy, Vcr, Mtx, CCNU/ } \\
\text { Vcr, BCNU, Proc, Hydroxy, Cis, Ara-C }\end{array}$ & DOD 3 - 5 mos \\
\hline Agranovich (1992) [54] & $33 \mathrm{mos}$ & 1 & Cis, Doxo & DOD 8 mos \\
\hline Weinblatt (1992) [55] & - & 1 & Vcr, Act-D, Doxo, IT Mtx, IT Ara-C, IT HC & NED 5 + yrs \\
\hline Hanna (1993) [56] & 8 mos - 6 yrs & 3 & $\begin{array}{l}\text { Vcr, VP-16, Cis, Cy, Vcr, nitrogen mustard, IT } \\
\text { Mtx/Ifos, VP-16, Carbo }\end{array}$ & DOD 6 - 15 mos \\
\hline Olson (1995) [47] & 18 mos - 5 yrs & 3 & $\begin{array}{l}\text { IRS III based (Vcr, Cis, Doxo, Cy, VP-16, } \\
\text { Act-D, IT Mtx, IT Ara-C, IT HC) }\end{array}$ & NED 6 - 42 mos \\
\hline Dang (2003) [57] & 4 wks - 25 mos & 3 & $\begin{array}{l}\text { Vcr, Cy, Act-D, Doxo, Vcr, VP-16, Cis, Cy, } \\
\text { Doxo, Ifos, IT thio/VP-16, Cis }\end{array}$ & DOD 5 mos - 1 year \\
\hline $\begin{array}{l}\text { Izychka-Swieszewska } \\
\text { (2003) [58] }\end{array}$ & 5 mos & & $\begin{array}{l}\text { 8-in-1 (Vcr, CCNU, Proc, Hydroxy, Cis, Ara-C, } \\
\text { Cy, MP) }\end{array}$ & DOD 8 mos \\
\hline Wharton (2003) [59] & 31 mos - 14 yrs & 3 & $\begin{array}{l}\text { UKCCSG SIOP PNET (Vcr, VP-16, Carbo, } \\
\text { Cy)/UKCCSG infant brain tumor protocol (Vcr, } \\
\text { Carbo, Cy, Mtx, Cis) }\end{array}$ & $\begin{array}{l}\text { DOD } 11 \text { mos } \\
\text { AWD at } 1 \text { year } \\
\text { NED } 4 \text { yrs }\end{array}$ \\
\hline $\begin{array}{l}\text { Zimmerman (2005) } \\
{[60]}\end{array}$ & 14 mos - 11 yrs & 4 & $\begin{array}{l}\text { DFCI/IRS III modified* (Vcr, Cis, Doxo, } \\
\text { Dexraz, Cy, VP-16, Actino, Tmz, IT Mtx, IT } \\
\text { Ara-C, IT HC) }\end{array}$ & NED 33 mos - 4 yrs \\
\hline Chen (2006) [28] & $\begin{array}{l}24 \text { mos }-11.2 \\
\text { yrs }\end{array}$ & 11 & $\begin{array}{l}\text { VIP (Vinb, Ifos, Cis), IT Mtx +/-, ACNU/ICE + } \\
\text { CECAT (Cy, VP-16, Carbo, Thio) }\end{array}$ & $\begin{array}{l}\text { DOD } 7 \text { - } 24 \text { mos } \\
\text { AWD } 15 \text { - } 17 \text { mos } \\
\text { NED } 35 \text { - } 105 \text { mos }\end{array}$ \\
\hline Fidani (2009) [61] & $\begin{array}{l}16 \text { mos - } 8.6 \\
\text { yrs }\end{array}$ & 8 & $\begin{array}{l}\text { ICE + CECAT (Cy, VP-16, Carbo, Thio)/ICE/ } \\
\text { ICE+TMZ }\end{array}$ & $\begin{array}{l}\text { DOD } 8 \text { - } 13 \text { mos } \\
\text { AWD } 5 \text { - } 38 \text { mos } \\
\text { NED } 101 \text { - } 105 \text { mos }\end{array}$ \\
\hline Gardner (2008) [62] & $4-52$ mos & 13 & $\begin{array}{l}\text { HSI (Induction: Cis, VP-16, Cy, Vcr, Consolid: } \\
\text { Carbo, Thio, VP-16, ASCR)/HS II (same as HS } \\
\text { I plus Mtx in Induction) }\end{array}$ & $\begin{array}{l}\text { DOD/DOC } 0.5-11.5 \\
\text { mos } \\
\text { NED } 42-67 \text { mos }\end{array}$ \\
\hline Lassaletta (2009) [63] & $8 \mathrm{mos}$ & & $\begin{array}{l}\text { ACNS } 0121 \text { (Vcr, Cy, Carbo, VP-16) and IT } \\
\text { depot Ara-C }\end{array}$ & DOD 2 mos \\
\hline \multirow[t]{4}{*}{ Biswas (2009) [64] } & 6 years & & GTR, CSRT, VAC (Vcr, Doxo, Cy) & NED 24 mos \\
\hline & 6 years & & STR, VAC & $\mathrm{DOD}<2 \mathrm{mos}$ \\
\hline & 5 years & & STR, CSRT, VAC & AWD? \\
\hline & $18 \mathrm{mos}$ & & STR, ICE & $\begin{array}{l}\text { DOD }<2 \text { mos } \\
\text { DOD/DOC } 1-24\end{array}$ \\
\hline Chi (2009) [45] & 4 mos -8.4 yrs & 18 & $\begin{array}{l}\text { GTR, CRT, modified IRS-III (Vcr, Dactino, Cy, } \\
\text { Cis, Doxo, Tmz, IT Mtx, Ara-C, HC) }\end{array}$ & $\begin{array}{l}\text { mos } \\
\text { AWD } 17 \text { - } 34 \text { mos } \\
\text { NED } 18 \text { - } 40 \text { mos }\end{array}$ \\
\hline Ertan (2009) [65] & 8 mos - 8 yrs & 2 & ICE & DOD 4 - 5 mos \\
\hline Wang (2009) [66] & $16-42 \mathrm{mos}$ & & Cis, Ifos, VP-16, IT ACNU/TMZ** & $\begin{array}{l}\text { AWD } 12 \text { mos } \\
\text { NED } 59 \text { mos }\end{array}$ \\
\hline
\end{tabular}

Ara-C: cytarabine; AWD: alive with disease; Bx: biopsy; Carbo: carboplatin; Cis: cisplatin; CSRT: craniospinal radiation therapy; Cy: cyclophosphamide; DOC: dead of complications; DOD: dead of disease; EBRT: external beam radiation therapy; GTR: gross total resection; HC: hydrocortisione; Hydroxy: hydroxyurea; ICE: ifosphamide, carboplatin, etoposide; Ifos: ifosphamide; IT: intrathecal; Mtx: methotrexate; NED: no evidence of disease; Proc: procarbazine; STR: subtotal resection; Tmz: temozolomide; Vcr: vincristine; VP-16: etoposide. * One patient received this second-line. ${ }^{*}$ One patient only received second-line chemotherapy.

the maximum dose to the target tissue while sparing normal tissues from much of the entry dose and the entire exit dose. This occurs as protons lose only a small amount of their energy in tissue until they reach the target tissue, after which the residual energy is rapidly lost, resulting in a steep treat- ment gradient [49]. Therefore, the use of proton-beam radiation for craniospinal treatment may allow a partial sparing of vertebral body radiation exposure, lessening the impact on this major component of hematopoeisis and lessening the degree of myelotoxcity. 
Laboratory studies have focused on establishing an AT/ $\mathrm{RT}$ in vitro cell culture model on which preclinical studies can investigate both chemotherapeutic agents as well as targeted therapies [50-53]. Insulin-growth factor-1 receptor (IGF-1R) inhibition has been shown to sensitize cells to both chemotherapy and radiation [53]. Using AT/RT cells cultured from CSF, Narendran noted growth inhibition with low concentrations of arsenic trioxide, Prima-1 (targets mutant p53 proteins), oxaliplatin, cisplatin and rebeccamycin. Thalidomide, etoposide, cytarabine and paclitaxel had intermediate MICs. The optimal treatment remains to be defined, but the increasing recognition of this disease and the development of good laboratory models will hopefully accelerate therapeutic advances.

\section{Conclusion}

AT/RT remains a rare adult disease. However, as our knowledge of AT/RTs increases we anticipate that there will be more standardization of treatment. Aggressive resection followed by multimodality treatment appears to yield more long-term survivors. In adults, although the use of RT does not convey the same devastating developmental arrest, there are still reasons to minimize the effects to normal tissues particularly bone marrow, supporting the use of proton radiation, particularly since CSRT is a standard treatment. Although the optimal chemotherapy regimen has not been defined for adults with AT/RT, several regimens have been used with evidence of activity. Further advances in treatment will likely require more laboratory studies generating novel treatment regimens for clinical trial testing. The rarity of adult AT/RT suggests that treatment regimens will continue to rely on advances in pediatric treatments.

\section{Conflicts of Interest}

The authors have no relevant conflicts of interest to disclose.

\section{References}

1. Beckwith JB, Palmer NF. Histopathology and prognosis of Wilms tumors: results from the First National Wilms' Tumor Study. Cancer 1978;41(5):1937-1948.

2. Haas JE, Palmer NF, Weinberg AG, Beckwith JB. Ultrastructure of malignant rhabdoid tumor of the kidney. A distinctive renal tumor of children. Hum Pathol 1981;12(7):646-657.

3. Montgomery P, Kuhn JP, Berger PE. Rhabdoid tumor of the kidney: a case report. Urol Radiol 1985;7(1):42-44.

4. Rorke LB, Packer RJ, Biegel JA. Central nervous system atypical teratoid/rhabdoid tumors of infancy and child- hood: definition of an entity. J Neurosurg 1996;85(1):5665.

5. Rickert $\mathrm{CH}$, Paulus W. Epidemiology of central nervous system tumors in childhood and adolescence based on the new WHO classification. Childs Nerv Syst 2001;17(9):503-511.

6. Allen JC, Judkins AR, Rosenblum MK, Biegel JA. Atypical teratoid/rhabdoid tumor evolving from an optic pathway ganglioglioma: case study. Neuro Oncol 2006;8(1):79-82.

7. Tekautz TM, Fuller CE, Blaney S, Fouladi M, Broniscer A, Merchant TE, Krasin M, et al. Atypical teratoid/ rhabdoid tumors (ATRT): improved survival in children 3 years of age and older with radiation therapy and high-dose alkylator-based chemotherapy. J Clin Oncol 2005;23(7):1491-1499.

8. Swensen JJ, Keyser J, Coffin CM, Biegel JA, Viskochil DH, Williams MS. Familial occurrence of schwannomas and malignant rhabdoid tumour associated with a duplication in SMARCB1. J Med Genet 2009;46(1):68-72.

9. Horn M, Schlote W, Lerch KD, Steudel WI, Harms D, Thomas E. Malignant rhabdoid tumor: primary intracranial manifestation in an adult. Acta Neuropathol 1992;83(4):445-448.

10. Fisher BJ, Siddiqui J, Macdonald D, Cairney AE, Ramsey D, Munoz D, Del Maestro R. Malignant rhabdoid tumor of brain: an aggressive clinical entity. Can J Neurol Sci 1996;23(4):257-263.

11. Ashraf R, Bentley RC, Awan AN, McLendon RE, Ragozzino MW. Implantation metastasis of primary malignant rhabdoid tumor of the brain in an adult (one case report). Med Pediatr Oncol 1997;28(3):223-227.

12. Byram D. Regarding Weiss et al., IJROBP 41:103-109; 1998. Int J Radiat Oncol Biol Phys 1999;45(1):247.

13. Kuge A, Kayama T, Tsuchiya D, Kawakami K, Saito S, Nakazato Y, Suzuki H. [Suprasellar primary malignant rhabdoid tumor in an adult: a case report]. No Shinkei Geka 2000;28(4):351-358.

14. Arrazola J, Pedrosa I, Mendez R, Saldana C, Scheithauer BW, Martinez A. Primary malignant rhabdoid tumour of the brain in an adult. Neuroradiology 2000;42(5):363367.

15. Lutterbach J, Liegibel J, Koch D, Madlinger A, Frommhold H, Pagenstecher A. Atypical teratoid/rhabdoid tumors in adult patients: case report and review of the literature. J Neurooncol 2001;52(1):49-56.

16. Bruch LA, Hill DA, Cai DX, Levy BK, Dehner LP, Perry A. A role for fluorescence in situ hybridization detection of chromosome 22q dosage in distinguishing atypical teratoid/rhabdoid tumors from medulloblastoma/ central primitive neuroectodermal tumors. Hum Pathol 2001;32(2):156-162.

17. Pimentel J, Silva R, Pimentel T. Primary malignant rhabdoid tumors of the central nervous system: consid- 
erations about two cases of adulthood presentation. J Neurooncol 2003;61(2):121-126.

18. Kawaguchi T, Kumabe T, Watanabe M, Tominaga $\mathrm{T}$. Atypical teratoid/rhabdoid tumour with leptomeningeal dissemination in an adult. Acta Neurochir (Wien) 2004;146(9):1033-1038; discussion 1038.

19. Kachhara R, Retnam TM, Kumar S, Nair S, Bhattacharya RN, Krishnamoorthy T, Radhakrishnan VV. Rhabdoid tumor of the thalamus. Neurol India 2003;51(2):273274.

20. Raisanen J, Biegel JA, Hatanpaa KJ, Judkins A, White CL, Perry A. Chromosome 22q deletions in atypical teratoid/rhabdoid tumors in adults. Brain Pathol 2005;15(1):23-28.

21. Erickson ML, Johnson R, Bannykh SI, de Lotbiniere A, Kim JH. Malignant rhabdoid tumor in a pregnant adult female: literature review of central nervous system rhabdoid tumors. J Neurooncol 2005;74(3):311-319.

22. Ingold B, Moschopulos M, Hutter G, Seeger H, Rothlisberger B, Landolt H, Yonekawa Y, et al. Abdominal seeding of an atypical teratoid/rhabdoid tumor of the pineal gland along a ventriculoperitoneal shunt catheter. Acta Neuropathol 2006;111(1):56-59.

23. Rezanko T, Tunakan M, Kahraman A, Sucu HK, Gelal F, Akkol I. Primary rhabdoid tumor of the brain in an adult. Neuropathology 2006;26(1):57-61.

24. Zarovnaya EL, Pallatroni HF, Hug EB, Ball PA, Cromwell LD, Pipas JM, Fadul CE, et al. Atypical teratoid/ rhabdoid tumor of the spine in an adult: case report and review of the literature. J Neurooncol 2007;84(1):49-55.

25. Samaras V, Stamatelli A, Samaras E, Stergiou I, Konstantopoulou P, Varsos V, Judkins AR, et al. Atypical teratoid/rhabdoid tumor of the central nervous system in an 18-year-old patient. Clin Neuropathol 2009;28(1):110.

26. Cossu A, Massarelli G, Manetto V, Viale G, Tanda F, Bosincu L, Iuzzolino P, et al. Rhabdoid tumours of the central nervous system. Report of three cases with immunocytochemical and ultrastructural findings. Virchows Arch A Pathol Anat Histopathol 1993;422(1):8185.

27. Balaton AJ, Vaury P, Videgrain M. Paravertebral malignant rhabdoid tumor in an adult. A case report with immunocytochemical study. Pathol Res Pract 1987;182(5):713-718.

28. Chen YW, Wong TT, Ho DM, Huang PI, Chang KP, Shiau CY, Yen SH. Impact of radiotherapy for pediatric CNS atypical teratoid/rhabdoid tumor (single institute experience). Int J Radiat Oncol Biol Phys 2006;64(4):10381043.

29. Chacko G, Chacko AG, Dunham CP, Judkins AR, Biegel JA, Perry A. Atypical teratoid/rhabdoid tumor arising in the setting of a pleomorphic xanthoastrocytoma. J Neurooncol 2007;84(2):217-222.
30. Makuria AT, Rushing EJ, McGrail KM, Hartmann DP, Azumi N, Ozdemirli M. Atypical teratoid rhabdoid tumor (AT/RT) in adults: review of four cases. J Neurooncol 2008;88(3):321-330.

31. Arita K, Sugiyama K, Sano T, Oka H. Atypical teratoid/ rhabdoid tumour in sella turcica in an adult. Acta Neurochir (Wien) 2008;150(5):491-495; discussion 496.

32. Packer RJ, Biegel JA, Blaney S, Finlay J, Geyer JR, Heideman R, Hilden J, et al. Atypical teratoid/rhabdoid tumor of the central nervous system: report on workshop. J Pediatr Hematol Oncol 2002;24(5):337-342.

33. Judkins AR. Immunohistochemistry of INI1 expression: a new tool for old challenges in CNS and soft tissue pathology. Adv Anat Pathol 2007;14(5):335-339.

34. Sugita Y, Takahashi Y, Hayashi I, Morimatsu M, Okamoto K, Shigemori M. Pineal malignant rhabdoid tumor with chondroid formation in an adult. Pathol Int 1999;49(12):1114-1118.

35. Meyers SP, Khademian ZP, Biegel JA, Chuang SH, Korones DN, Zimmerman RA. Primary intracranial atypical teratoid/rhabdoid tumors of infancy and childhood: MRI features and patient outcomes. AJNR Am J Neuroradiol 2006;27(5):962-971.

36. Oka H, Scheithauer BW. Clinicopathological characteristics of atypical teratoid/rhabdoid tumor. Neurol Med Chir (Tokyo) 1999;39(7):510-517; discussion 517-518.

37. Biegel JA, Fogelgren B, Zhou JY, James CD, Janss AJ, Allen JC, Zagzag D, et al. Mutations of the INI1 rhabdoid tumor suppressor gene in medulloblastomas and primitive neuroectodermal tumors of the central nervous system. Clin Cancer Res 2000;6(7):2759-2763.

38. Biegel JA, Kalpana G, Knudsen ES, Packer RJ, Roberts CW, Thiele CJ, Weissman B, et al. The role of INI1 and the SWI/SNF complex in the development of rhabdoid tumors: meeting summary from the workshop on childhood atypical teratoid/rhabdoid tumors. Cancer Res 2002;62(1):323-328.

39. Burger PC, Yu IT, Tihan T, Friedman HS, Strother DR, Kepner JL, Duffner PK, et al. Atypical teratoid/rhabdoid tumor of the central nervous system: a highly malignant tumor of infancy and childhood frequently mistaken for medulloblastoma: a Pediatric Oncology Group study. Am J Surg Pathol 1998;22(9):1083-1092.

40. Ho DM, Hsu CY, Wong TT, Ting LT, Chiang H. Atypical teratoid/rhabdoid tumor of the central nervous system: a comparative study with primitive neuroectodermal tumor/medulloblastoma. Acta Neuropathol 2000;99(5):482-488.

41. Kalpana GV, Marmon S, Wang W, Crabtree GR, Goff SP. Binding and stimulation of HIV-1 integrase by a human homolog of yeast transcription factor SNF5. Science 1994;266(5193):2002-2006.

42. Versteege I, Sevenet N, Lange J, Rousseau-Merck MF, Ambros P, Handgretinger R, Aurias A, et al. Truncating 
mutations of hSNF5/INI1 in aggressive paediatric cancer. Nature 1998;394(6689):203-206.

43. Biegel JA. Cytogenetics and molecular genetics of childhood brain tumors. Neuro Oncol 1999;1(2):139-151.

44. Biegel JA, Rorke LB, Packer RJ, Emanuel BS. Monosomy 22 in rhabdoid or atypical tumors of the brain. $\mathrm{J}$ Neurosurg 1990;73(5):710-714.

45. Chi SN, Zimmerman MA, Yao X, Cohen KJ, Burger P, Biegel JA, Rorke-Adams LB, et al. Intensive multimodality treatment for children with newly diagnosed CNS atypical teratoid rhabdoid tumor. J Clin Oncol 2009;27(3):385-389.

46. Hilden JM, Meerbaum S, Burger P, Finlay J, Janss A, Scheithauer BW, Walter AW, et al. Central nervous system atypical teratoid/rhabdoid tumor: results of therapy in children enrolled in a registry. J Clin Oncol 2004;22(14):2877-2884.

47. Olson TA, Bayar E, Kosnik E, Hamoudi AB, Klopfenstein KJ, Pieters RS, Ruymann FB. Successful treatment of disseminated central nervous system malignant rhabdoid tumor. J Pediatr Hematol Oncol 1995;17(1):71-75.

48. Russell WJ, Yoshinagah, Antoku S, Mizuno M. Active bone marrow distribution in the adult. Br J Radiol 1966;39(466):735-739.

49. Yock TI, Tarbell NJ. Technology insight: Proton beam radiotherapy for treatment in pediatric brain tumors. Nat Clin Pract Oncol 2004;1(2):97-103; quiz 101 p following 111.

50. Furchert SE, Lanvers-Kaminsky C, Juurgens H, Jung M, Loidl A, Fruhwald MC. Inhibitors of histone deacetylases as potential therapeutic tools for high-risk embryonal tumors of the nervous system of childhood. Int J Cancer 2007;120(8):1787-1794.

51. Maris JM, Courtright J, Houghton PJ, Morton CL, Kolb EA, Lock R, Tajbakhsh M, et al. Initial testing (stage 1) of sunitinib by the pediatric preclinical testing program. Pediatr Blood Cancer 2008;51(1):42-48.

52. Narendran A, Coppes L, Jayanthan A, Coppes M, Teja B, Bernoux D, George D, et al. Establishment of atypical-teratoid/rhabdoid tumor (AT/RT) cell cultures from disseminated CSF cells: a model to elucidate biology and potential targeted therapeutics. J Neurooncol 2008;90(2):171-180.

53. D’Cunja J, Shalaby T, Rivera P, von Buren A, Patti R, Heppner FL, Arcaro A, et al. Antisense treatment of IGF-IR induces apoptosis and enhances chemosensitivity in central nervous system atypical teratoid/rhabdoid tumours cells. Eur J Cancer 2007;43(10):1581-1589.

54. Agranovich AL, Ang LC, Griebel RW, Kobrinsky NL, Lowry N, Tchang SP. Malignant rhabdoid tumor of the central nervous system with subarachnoid dissemination. Surg Neurol 1992;37(5):410-414.

55. Weinblatt M, Kochen J. Rhabdoid tumor of the central nervous system. Med Pediatr Oncol 1992;20(3):258.

56. Hanna SL, Langston JW, Parham DM, Douglass EC. Primary malignant rhabdoid tumor of the brain: clinical, imaging, and pathologic findings. AJNR Am J Neuroradiol 1993;14(1):107-115.

57. Dang T, Vassilyadi M, Michaud J, Jimenez C, Ventureyra EC. Atypical teratoid/rhabdoid tumors. Childs Nerv Syst 2003;19(4):244-248.

58. Izycka-Swieszewska E, Debiec-Rychter M, Wasag B, Wozniak A, Gasecki D, Plata-Nazar K, Bartkowiak J, et al. A unique occurrence of a cerebral atypical teratoid/ rhabdoid tumor in an infant and a spinal canal primitive neuroectodermal tumor in her father. J Neurooncol 2003;61(3):219-225.

59. Wharton SB, Wardle C, Ironside JW, Wallace WH, Royds JA, Hammond DW. Comparative genomic hybridization and pathological findings in atypical teratoid/rhabdoid tumour of the central nervous system. Neuropathol Appl Neurobiol 2003;29(3):254-261.

60. Zimmerman MA, Goumnerova LC, Proctor M, Scott RM, Marcus K, Pomeroy SL, Turner CD, et al. Continuous remission of newly diagnosed and relapsed central nervous system atypical teratoid/rhabdoid tumor. J Neurooncol 2005;72(1):77-84.

61. Fidani P, De Ioris MA, Serra A, De Sio L, Ilari I, Cozza $\mathrm{R}$, Boldrini R, et al. A multimodal strategy based on surgery, radiotherapy, ICE regimen and high dose chemotherapy in atypical teratoid/rhabdoid tumours: a single institution experience. J Neurooncol 2009;92(2):177183.

62. Gardner SL, Asgharzadeh S, Green A, Horn B, McCowage G, Finlay J. Intensive induction chemotherapy followed by high dose chemotherapy with autologous hematopoietic progenitor cell rescue in young children newly diagnosed with central nervous system atypical teratoid rhabdoid tumors. Pediatr Blood Cancer 2008;51(2):235-240.

63. Lassaletta A, Lopez-Ibor B, Mateos E, Gonzalez-Vicent M, Perez-Martinez A, Sevilla J, Diaz MA, et al. Intrathecal liposomal cytarabine in children under 4 years with malignant brain tumors. J Neurooncol 2009.

64. Biswas A, Goyal S, Puri T, Das P, Sarkar C, Julka PK, Bakhshi S, et al. Atypical teratoid rhabdoid tumor of the brain: case series and review of literature. Childs Nerv Syst 2009.

65. Ertan Y, Sezak M, Turhan T, Kantar M, Ersahin Y, Mutluer S, Vergin C, et al. Atypical teratoid/rhabdoid tumor of the central nervous system: clinicopathologic and immunohistochemical features of four cases. Childs Nerv Syst 2009;25(6):707-711.

66. Wang CH, Hsu TR, Wong TT, Chang KP. Efficacy of temozolomide for recurrent embryonal brain tumors in children. Childs Nerv Syst 2009;25(5):535-541. 